\title{
THE CONTRIBUTION OF SPRINGTIME AND AUTUMN GLASS EELS (ANGUILLA ANGUILLA) TO STOCK : RESULTS BASED ON OTOLITH MORPHOMETRY.
}

\author{
C. BRIAND (1), B. MOUNAIX (2), D. FATIN (1), E. FEUNTEUN (3)
}

(1) Institution d'Aménagement de la Vilaine, Boulevard de Bretagne, 56130 La Roche Bernard, France.

(2) Fish Pass, 8 allée de Guerlédan, Z.A. Parc rocade Sud, 35135 Chantepie, France.

(3) LBEM, Université de La Rochelle, Rue E. Fermi, 17042 La Rochelle, France

\begin{abstract}
A double mark, called a transition ring, or elver mark, was identifiable in light microscopy on otoliths of young yellow eels. In the Vilaine watershed, the radius of this mark decreased from $178 \mu \mathrm{m}$ in yellow eels corresponding to glass eels arriving in autumn 1997 to $163 \mu \mathrm{m}$ in yellow eels arriving in spring 1998. The mean transition ring radius of the freshwater eel population in the Vilaine river had an intermediate value between spring and autumn recruits. This implies that it consisted of a mixture of spring and autumn recruits. In the Vilaine estuary and the Frémur populations, the mean radius of the transition rings was close to the autumn one. The springtime recruits formed $68 \%$ of freshwater and $15 \%$ of estuarine population in the Vilaine for the 1998 cohort. This result was in sharp contrast with the available assessments of recruitment, which both in estuary and in the fluvial part of the watershed, were dominated by spring recruits. This contrast is possibly the consequence of density-dependent mortality, which would have been particularly important in springtime for glass eels whose migration was inhibited by the dam.
\end{abstract}

Key-words: Anguilla anguilla, eel, mortality, transition ring, season, estuary.

\section{CONTRIBUTION DES RECRUTEMENTS PRINTANIERS ET AUTOMNAUX DE CIVELLES (ANGUILLA ANGUILLA) : RESULTATS BASÉS SUR LA MORPHOMÉTRIE DE L'OTOLITHE.}

\section{RÉSUMÉ}

Une double marque, nommée anneau de transition est identifiable en microscopie optique sur les otolithes des jeunes anguilles. Sur le bassin versant de la Vilaine, le rayon de cette marque passe de $178 \mu \mathrm{m}$ chez les anguillettes correspondant à des civelles arrivées à l'automne 1997, à $163 \mu \mathrm{m}$ chez des anguillettes correspondant à des recrues du printemps 1998. Le rayon moyen de la marque de transition de la population d'anguille fluviale de la Vilaine est intermédiaire entre celui des recrues printanières et automnales. Ceci implique que les populations d'anguille fluviale de Vilaine résultent d'un mélange de recrues printanières et automnales. Mais pour les populations de l'estuaire de Vilaine et du Frémur le rayon de transition est proche de celui des recrues automnales. La proportions de recrues printanières s'établit à $68 \%$ en eau douce et $15 \%$ en estuaire pour la cohorte 1998 en Vilaine. Les recrutements fluviaux et 
estuariens de civelles correspondant à l'échappement à la pêche sont au contraire dominés par les civelles printanières qui forment l'essentiel de l'effectif. Cette opposition pourrait provenir d'une mortalité densité-dépendante, particulièrement importante au printemps pour les civelles bloquées au pied du barrage. estuaire.

Mots-clés : Anguilla anguilla, anguilles, mortalité, anneau de transition, saison,

\section{INTRODUCTION}

The decline in glass eel (Anguilla anguilla) recruitment on the Atlantic coasts (MORIARTY and DEKKER, 1997) may result in a change in yellow eel population structure, density and geographical extent, at the edge of the distribution area. However, these changes may not occur in situations where density dependent factors moderate the effect of a fall in recruitment (SVEDÄNG, 1999; KNIGHTS et al., 2001). Atlantic facing estuaries form a particular context because they receive, as a rough estimate, $76 \%$ of the total recruitment but only account for $7 \%$ of the distribution area in Europe (DEKKER, 2000). In these locations, the short duration of the estuarine migration implies that only juvenile yellow eels colonize the watershed, and that glass eels remain for a while in, or close to, the estuary. During this period, density dependent regulations will affect both mortality and migration. Mortality of both glass and juvenile eels is determined by the difference between carrying capacity and recruitment. Density dependent regulations will also play a role in the colonisation process as population pressure in the lower reaches of the catchments would enhance upstream migration (MORIARTY, 1986; LOBÓN-CERVIÁ et al., 1995). The probability for a glass eel of surviving may vary depending on its energy reserves (CHARLON and BLANC, 1982; BOËTIUS and BOËTIUS, 1989; GUÉRAULT et al., 1995; DE CASAMAJOR et al., 2001a). Glass eels entering the estuary from August to November have the best condition factor and are present at a lower density during glass eel stage than glass eels arriving in winter or springtime. Therefore, they are supposed to have a better survival rate.

The aim of this paper is to analyse the respective contribution to the watershed subunit of stock of early autumn recruits compared to spring recruitment in the Vilaine watershed. In this river, almost no glass eel escapes capture from the fishery during the fishing season from mid-December to April (BRIAND et al., In press). Recruitment is therefore limited to the small quantities of autumn glass eel arriving before and at the beginning of the fishing season, in November, when fishing is only conducted by a few boats. Most of the recruits consist of spring glass eels arriving after the closure of the fishery.

A method for differentiating spring from autumn recruits at the adult stage based on otolith measurements is described in this paper. For all eel species, the transition ring (or elver mark) is formed on glass eel otoliths at the end of marine life (MICHAUD et al., 1988; LECOMTE-FINIGER, 1992; TZENG and TSAI, 1994; KAWAKAMI et al., 1998). This ring does not strictly correspond to the entry to freshwater, as it may already be observed in glass eels collected far from the coasts (LECOMTE-FINIGER et al., 1993; DE CASAMAJOR et al., 2001b); or deposited experimentally in full salinity water (CIERI and MC CLEAVE, 2001). In 1990, GUÉRAULT et al. (1992) described a seasonal decrease of the radius of the glass eel otolith, measured from the centre to the transition ring. This result suggests that it could be possible to distinguish the respective contributions of spring and autumn recruits to the whole population.

The objectives of this work are to show that there has been a seasonal decrease of the dimensions of the transition ring from autumn 1997 to spring 1998. We will identify two groups of yellow eels, one recruited in autumn and one in springtime. The 
distributions of the transition ring radius of three populations of yellow eels - collected on the freshwater parts of the Frémur and the Vilaine and in the Vilaine estuary - will then be compared with the spring and autumn groups previously described. Finally we will calculate the contribution of spring and autumn recruits to the 1997 and 1998 cohorts in the Vilaine. This contribution will be compared with the recruitments recorded at the glass eel stage and the possible consequences on glass eel mortality will be analysed.

\section{MATERIALS ET METHODS}

\section{Description of the study areas}

The Vilaine watershed is located on the southern coast of Brittany, in the NorthWest of France and covers $10400 \mathrm{~km}^{2}$. The eel population is separated into two distinct compartments by the Arzal dam, which delimitates the estuary, 12 kilometres from the river mouth (MOUNAIX, 1992). Glass eels concentrate at the bottom of the dam where the professional fishery applies heavy fishing pressure. Upstream from the dam, the Vilaine forms a $200 \mathrm{~m}$ wide river and separates into two tributaries (Figure 1). An eeltrapping ladder is located on the first dam of each stream, 45 and 80 kilometers from the estuary.

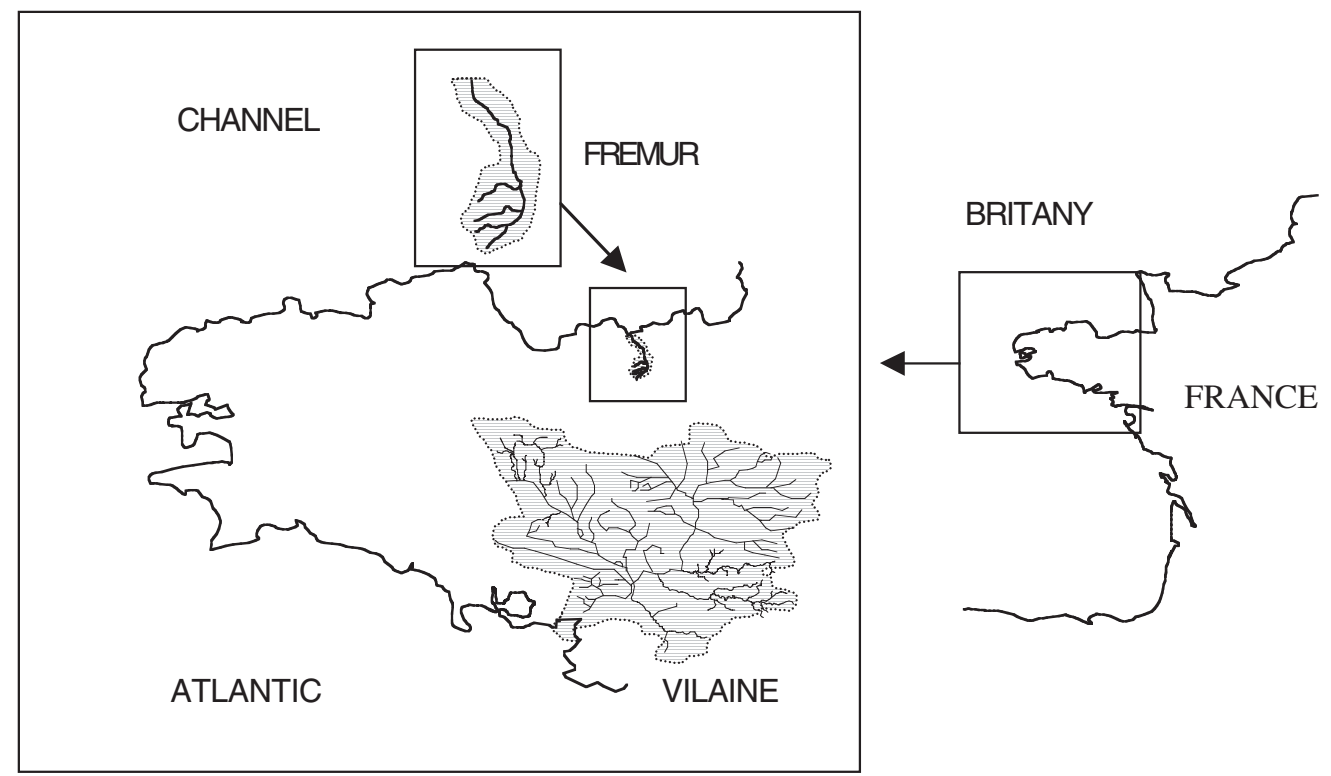

Figure 1

Location of the Frémur and Vilaine basins.

\section{Figure 1}

Localisation des bassins versants de la Vilaine et du Frémur.

The Frémur watershed is a short coastal stream $\left(60 \mathrm{~km}^{2}\right)$ located on the north coast of Brittany (Figure 1). It is obstructed by several dams, but the main one is equipped with both an eel lift and a trapping system (Bois Joli, $5 \mathrm{~km}$ from the estuary). The fishing pressure in the short estuary is very limited as there is no professional fishery and angling mainly focuses on game fish (FEUNTEUN et al., 1998).

\section{Sample collection}

We sampled 217 yellow eels in the Vilaine estuary. They were collected in 1998 and 1999 on the estuarine eel ladder, and in 1999 in the estuary from a commercial eel 
pot fisherman. We also collected 549 eels in the freshwater part of the Vilaine watershed in 1998 and 1999. Most eels were trapped on the two eel ladders located in the watershed but a small sample was added from an electrofishing operation in 1999. We also collected 120 eels by electrofishing from the freshwater part of the Frémur watershed in 2000 (Table 1). A total of 886 eels was therefore used for otolith extraction.

\section{Table 1}

Collection date and capture locations of eels used for otolith measurements.

\section{Tableau 1}

Lieu et date de collecte des anguilles pour réaliser l'otolithométrie.

\begin{tabular}{|c|c|c|}
\hline Place and date & $\mathrm{N}$ & sample (size range) \\
\hline \multicolumn{3}{|c|}{ Vilaine estuary } \\
\hline Estuarine trapping ladder, April-May 1998 & 47 & ( random) $70-220 \mathrm{~mm}$ \\
\hline Estuarine trapping ladder, Oct-Nov 1999 & 96 & Size graded (all sizes) \\
\hline Eel pot (fisherman) Oct-Nov 1999 & 74 & Size graded (all sizes) \\
\hline \multicolumn{3}{|c|}{ Vilaine Freshwater } \\
\hline River Claie, 80 km, electrofishing, Nov 1999 & 30 & Random (all sizes) \\
\hline La Potinais, 45 km, trapping ladder, June-Sept 1998 & 123 & Random $<120 \mathrm{~mm}(66-111 \mathrm{~mm})$ \\
\hline La Potinais, 45 km, trapping ladder, May-Sept 1999 & 285 & Random $<150 \mathrm{~mm}(65-139 \mathrm{~mm})$ \\
\hline Malon, 70 km, trapping ladder, 1999, June-Aug 1999 & 111 & Random $<150 \mathrm{~mm}(82-150 \mathrm{~mm})$ \\
\hline
\end{tabular}

Frémur freshwater

Electrofishing $2000 \quad 120 \quad$ Size graded (70-380)

\section{Otolith processing}

Otoliths were stored dry. They were observed using a binocular microscope (Olympus, $x 1$ to $x 63$ ) under reflected light. To enhance contrast, they were immersed in $70 \%$ ethanol. Otoliths of eels larger than $150 \mathrm{~mm}$ were embedded in resin (methacrylate, Dentsply) and mechanically ground (Dremel grounder, 600 grit emery disk) down to the sagittal plane before observation (MOUNAIX, 1992). Image analysis was used to identify and measure the radii of growth structures on otoliths. The inner translucent zone delimitated the nucleus whose border corresponded to the transition ring (LECOMTE-FINIGER et al. 1992; GUÉRAULT et al. 1992). Outward from the nucleus, the other measured marks (annuli=winter rings), have been described by PANFILI and XIMÉNĖS (1994) as the contrasting limit between translucent and opaque zones. They corresponded to fine translucent lines located at the beginning of each opaque zone (Figure 2).

\section{Seasonal group identification}

Spring eels were defined as glass eels recruited in springtime after the end of the fishing season (i.e. March to July). 1998 spring recruitment was marked with tetracycline hydrochloride (TCHC, method in ALCOBENDAS et al. 1991). A total of $210 \mathrm{~kg}$ of glass eels caught on the estuarine ladder in May and June 1998 (30\% of the spring recruitment) were marked. They were then released in freshwater above the ladder and next recaptured on the freshwater trapping ladders located upstream in the watershed. The tetracycline hydrochloride mark (ALCOBENDAS et al., 1991) was detected on otoliths using an epifluorescent light microscope (LEITZ Laborlux S, objective X10, eyepiece $\mathrm{x40}$ ). When exposed to U.V. light (excitation filter $450-490 \mathrm{~nm}$ ) the fluorochrome appeared as a bright yellow circular line in the otolith of marked eels (stop filter: $515 \mathrm{~nm}$ ). 


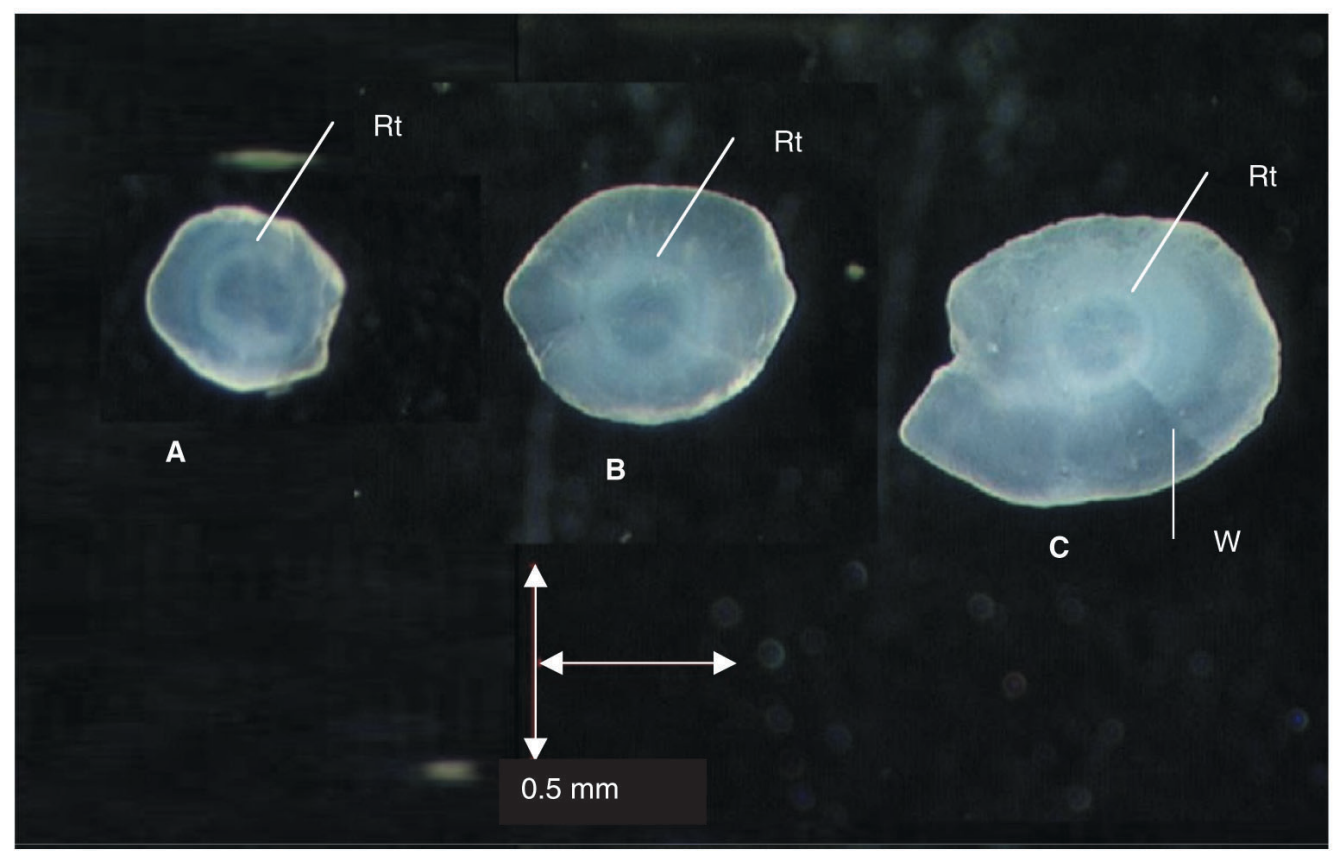

Figure 2

A/ Otolith without winter ring (=annulus), eel size $=76 \mathrm{~mm}$. B/ Otolith without winter ring, eel size $=96 \mathrm{~mm}$. C/ Otolith with one annulus, eel size $=121 \mathrm{~mm}$. $\mathrm{Rt}=$ transition ring, $\mathrm{W}=$ annulus.

\section{Figure 2}

A/ Otolithe sans anneau hivernal (=annulus), taille de l'anguille=76 mm. B/ Otolithe sans annulus, taille de l'anguille $=96 \mathrm{~mm}$. $\mathrm{C} /$ Otolithe avec un annulus, taille de l'anguille=121 $\mathrm{mm}$. Rt=rayon de transition, $\mathrm{W}=$ =annulus.

Juvenile eels were also collected in May and June 1998 on the Arzal estuarine eel ladder with the purpose of identifying Autumn 1997 recruits within the sample, on the basis of body size and otolith characteristics.

\section{Contribution of the seasonal groups to the population}

We measured the radii of the transition rings in the Vilaine freshwater, the Vilaine estuary and the Frémur (freshwater) samples. Their distributions were compared with one another and with spring and autumn recruits by Kolmogorov Smirnov nonparametric tests, because of the lack of homoscedasticity of data distributions. Next, we calculated the respective proportions of spring and autumn recruits within the estuarine and freshwater populations of the Vilaine. The calculation was based on transition ring radii obtained in autumn 1997 and spring 1998 samples. The proportion (p) of spring recruits was calculated by the following relationship: $M=p m_{1}+(1-p) m_{2}$, with $M=$ mean transition ring radius of freshwater or estuarine population, $m_{1}=$ mean transition ring radius of spring population, $\mathrm{m}_{2}=$ mean transition ring radius of autumn population.

In order to analyse the effects of cohort and location on transition ring variation, an analysis of variance (GLM SYSTAT) was performed on 853 transition ring radius values. Five cohorts (1995 to 1999) calculated from age and year of capture were selected. Data were also split into three sampling locations, Vilaine estuary, Vilaine freshwater and Frémur. The following model was used:

transition ring $=$ constant + location + cohort + cohort ${ }^{\star}$ location. 


\section{RESULTS}

Sample collection and otolith processing

On 886 eels, a total of 882 otolith pairs were processed, including 215 from the Vilaine estuary, 549 from freshwater bodies of the Vilaine river and 118 from the Frémur watershed system. Otolith observations provided measurements of 853 transition rings, 29 were not interpretable due to failure in otolith preparation.
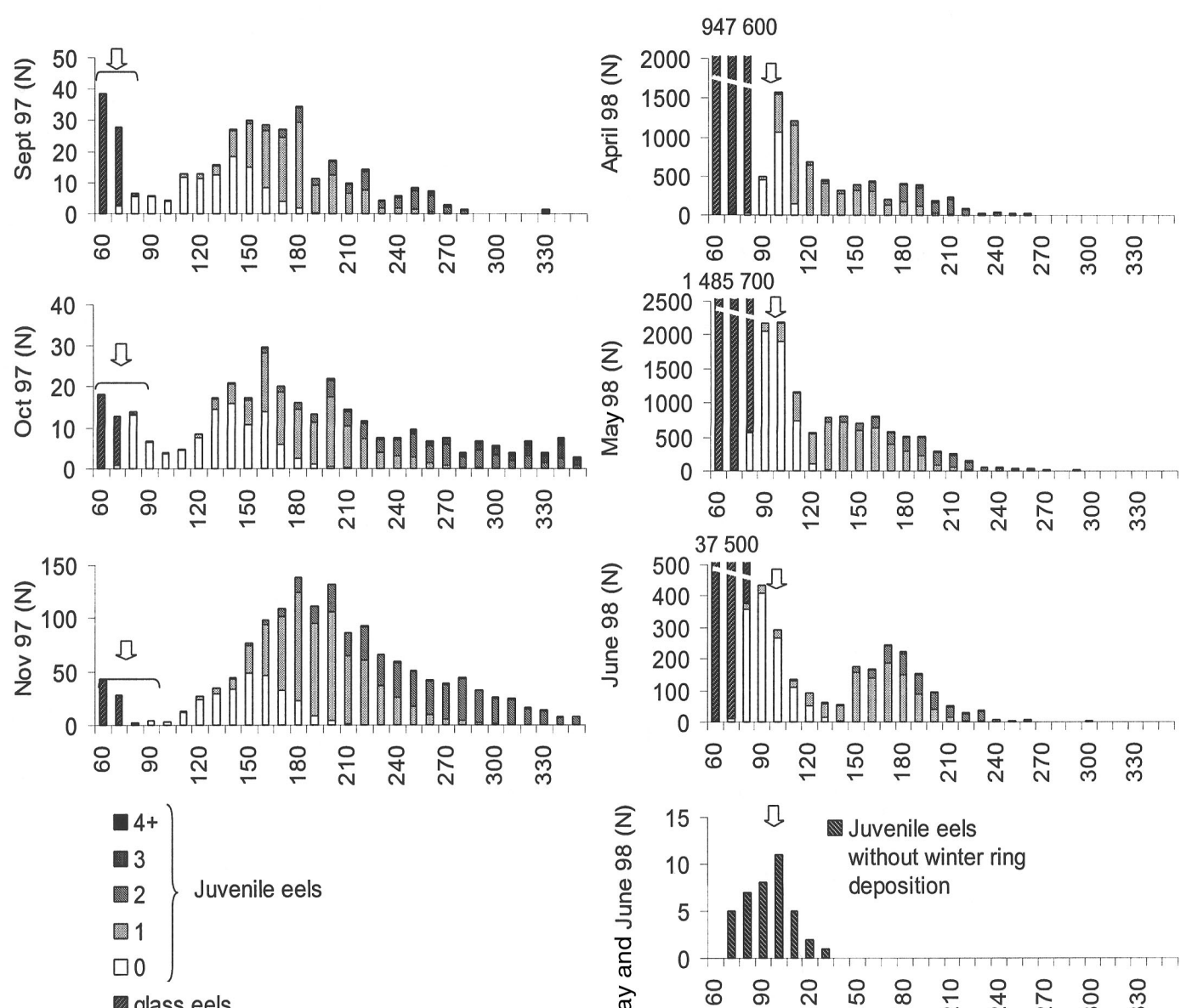

Figure 3

Size $(\mathrm{mm})$ and age distributions of glass eels and juvenile eels migrating at the Arzal trap. Size frequencies were calculated on a sample of at least 200 juvenile eels and extrapolated to the whole monthly catch. Glass eel migration in spring 1998 amounted to more than two million eels and is only indicated on the graph. The arrows correspond to the expected size of autumn recruits. Bottom right, size frequency of eels for which the winter 1997 translucent slow growth ring is not visible in spring 1998 (assumed autumn recruits).

Figure 3

Histogramme de fréquences de tailles et décomposition en âge des civelles et anguillettes en migration sur la passe d'Arzal. Les fréquences de tailles sont calculées sur la base d'un échantillon d'au moins 200 anguilles et extrapolées à l'ensemble de la capture mensuelle. La migration de civelles au printemps 1998 représentait plus de deux millions d'individus et est juste indiquée sur le graphique. Les flèches représentent la taille supposée des recrues automnales. En bas à droite, fréquence de tailles des anguilles dont l'anneau translucide de l'hiver 97 n'est pas visible au printemps 98 (recrutement automnal supposé). 


\section{Seasonal group identification}

Only 38 yellow eels were observed with one tetracycline mark and thus identified as 1998 spring recruits. The identification of 39 eels as autumn eels was based on body size, developmental stage and otolith criteria. In May and June on the Arzal eel ladder, we could easily distinguish spring recruits still at the glass eel stage from fully pigmented juvenile eels (stage VII ELIE et al., 1982). During the fishing season in the Vilaine the fishing pressure is very high. As a consequence, only the "young" i.e. early pigment stages are found viz. VB and VIA0. Old stages start to appear only after the end of the fishing season in April and May. In spring samples, the young yellow eel advanced stage identified them as being a different group from spring 1998 recruits and they were very likely recruited the previous year.

Between the young yellow eels, otolith criteria were then used to differentiate between autumn recruits and spring recruits of the previous year. Some eels had otoliths on which the marginal deposition of the opaque zone had not started, so the identification of the translucent winter ring was not possible. These eels were small with sizes ranging from 70 to $130 \mathrm{~mm}$. The eels with an opaque margin on otolith were larger with size ranging from 110 to $200 \mathrm{~mm}$. We assume that spring deposition of the opaque zone occurs later in eels arrived in autumn because of a slow growth resumption. Therefore, juvenile eels without opaque margin on otoliths were identified as eels recruited as glass eels in autumn.

Size and age distributions of monthly catches of migrating eels at Arzal dam are in accordance with those observations (Figure 3). The glass eels recruited in autumn grew slowly during winter to reach in May-June the size of small juvenile eels on whose otoliths the opaque margin had not yet been deposited (bottom right-hand histogram, Figure 3).

This assumption was further confirmed by the measurement of the radius of the transition ring, the largest rings being identified in the autumn group. The radius of the transition ring was significantly lower in spring recruits than in autumn recruits (means 163.4 and $178.3 \mu \mathrm{m}$ respectively, Kolmogorov Smirnov, $\mathrm{P}<0.001)$. This difference between autumn and spring recruits indicated that there was a seasonal variation in the transition ring and that this variation was still measurable at the yellow eel stage (Figure 4).

\section{Contribution of the seasonal groups to the population}

In samples coming from the Vilaine watershed, the transition ring radius distributions were different (KS $\mathrm{p}<0.05)$ between freshwater and the estuary. Their means (169.9 and $176.6 \mu \mathrm{m}$, respectively) were intermediate between typical spring and autumn values. In the Frémur, the radii of transition rings were the largest (mean $178.0 \mu \mathrm{m})$; and their distribution was different from both Vilaine freshwater $(\mathrm{KS} p<0.01)$ and Vilaine estuary (KS p<0.05) (Table 2).

Within estuarine samples, the transition ring distribution of eels collected on the eel ladder (mean 176,2 $\mu \mathrm{m}$ ) and in the estuary (mean 177,6 $\mu \mathrm{m}$ ) were not different ( $>0.5 \mathrm{KS}$ ) (Table 2).

The proportions of spring recruits $(p)$ were calculated from transition ring radii in the 1998 cohort as being $p=68 \%$ for freshwater and $p=15 \%$ for estuary.

In the GLM analysis, the crossed cohort ${ }^{\star}$ group effect was not significant. In the Vilaine basin, freshwater and estuarine samples were different $(p<0,001$, Bonferroni) (Figure 5A). There was however no difference between cohorts (Tukey $p>0,5$ ) (Figure $5 B$ ). Pairwise comparisons of cohort*location crossed effects were not significant except for the difference between freshwater 1998 and estuary 1996 (Tukey $p<0,05$ ) (Tables 3, Figure 5C). 


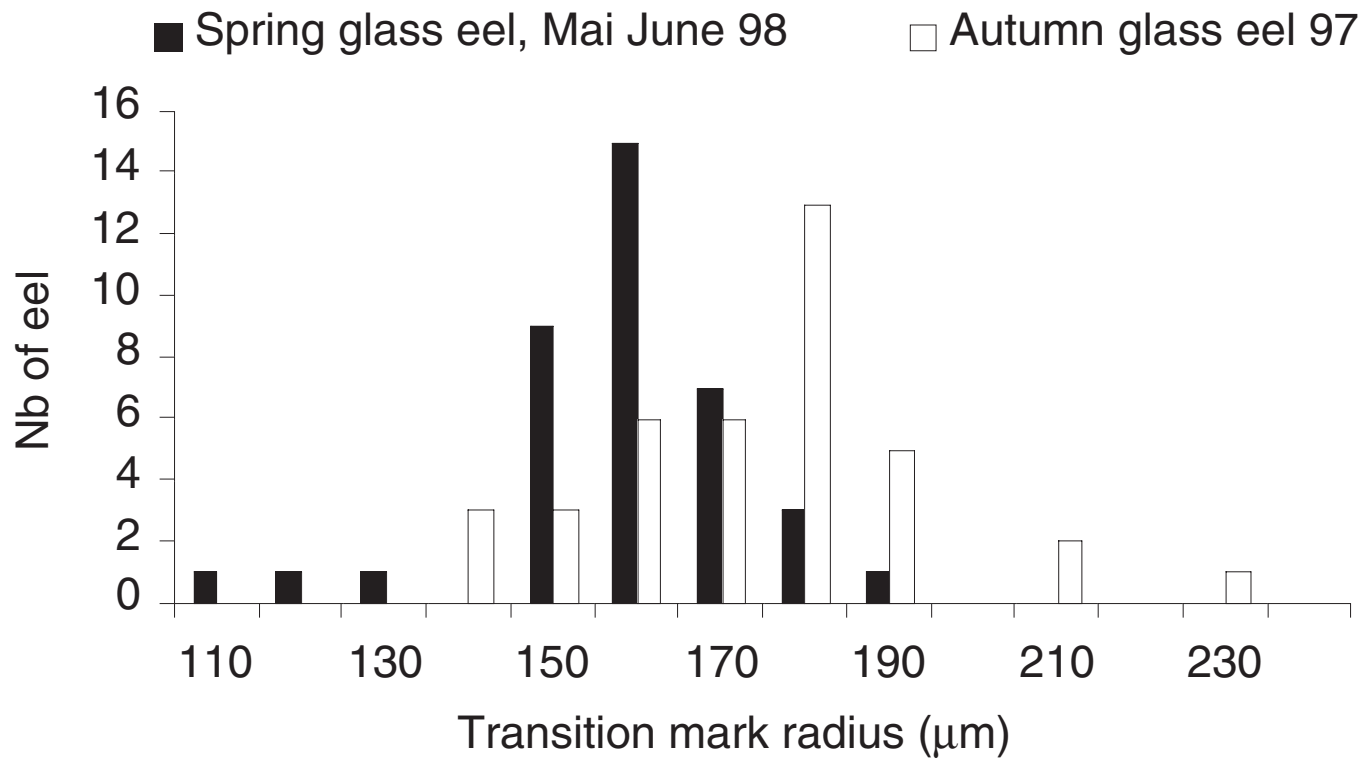

Figure 4

Distributions of the transition mark radius of 38 yellow eels corresponding to spring recruits and 39 yellow eel corresponding to autumn recruits.

\section{Figure 4}

Distributions des rayons des marques de transition sur les otolithes de 38 d'anguilles correspondant à des recrues printanières et 39 anguilles correspondant à des recrues d'automne.

\section{Table 2}

Measurements of transition ring radius of otoliths collected in the Vilaine in estuary (estu98-99), river (fresh98-99), in the groups corresponding to early glass eels (Fall97) and late (Spring98) arrivals, and on the Frémur (Frémur00). Kolmogorov Smirnov test statistics for between group comparison, ${ }^{* \star *} p<0.001$, ${ }^{\star *} \mathrm{p}<0.01,{ }^{*} \mathrm{P}<0.05$, NS non significant.

\section{Tableau 2}

Mesures des rayons de transition des otolithes prélevés en Vilaine en estuaire (estu 98-99), dans le fleuve (fresh98-99), dans les groupes correspondant aux recrutements de civelles précoces (automnales, Fall97) et tardives (printemps, Spring98) et sur le Frémur (Frémur00). Statistiques du test de Kolmogorov Smirnov pour la comparaison entre les groupes, ${ }^{\star \star \star} \mathrm{p}<0,001,{ }^{\star \star} \mathrm{p}<0,01,{ }^{*} \mathrm{P}<0,05$, NS non significatif.

\begin{tabular}{cccccccccc}
\hline & $\mathrm{N}$ & $\begin{array}{c}\text { Mean } \\
(\mu \mathrm{m})\end{array}$ & $\begin{array}{c}\text { Min } \\
(\mu \mathrm{m})\end{array}$ & $\begin{array}{c}\text { Max } \\
(\mu \mathrm{m})\end{array}$ & SD & Spring & Fresh & Estu & Fall \\
\hline Spring 98 & 38 & 163.4 & 117 & 190 & 14.8 & $*$ &. &. &. \\
Fresh 98-99 & 512 & 169.9 & 122 & 230 & 16.5 & $*$ &. &. &. \\
Estu 98-99 & 177 & 176.6 & 119 & 247 & 20.9 & $* * *$ & $*$ &. &. \\
Fall 97 & 39 & 178.3 & 140 & 230 & 19.2 & $* * *$ & $* *$ & NS &. \\
Frémur 00 & 116 & 178.0 & 149 & 213 & 13.8 & $* * *$ & $* * *$ & $*$ & NS \\
\hline
\end{tabular}




\section{Table 3}

Analysis of Variance (GLM) conducted on 853 transition ring values. Squared multiple $R=0.05$. Dependent variables have 5 levels for cohorts (1995 to 1999) and three levels for locations (estuary, freshwater, Frémur).

\section{Tableau 3}

Analyse de variance (GLM) réalisée sur 853 valeurs de rayons de transition. Carré du rapport de corrélation $R=0.05$. Les variables dépendantes ont cinq niveaux pour la Cohorte (1995 à 1999) et 3 pour le site de collecte (estuaire, fleuve (freshwater), Frémur).

\begin{tabular}{cccc}
\hline Source of variation & $\mathrm{df}$ & F-ratio & $\mathrm{P}$ \\
\hline Location & 2 & 6.345 & 0.002 \\
Cohort & 4 & 0.465 & 0.761 \\
Cohort*Location & 8 & 0.239 & 0.983 \\
Error & 838 & & \\
\hline
\end{tabular}

\section{DISCUSSION}

The first step in this work was to show that there was a seasonal variation of transition ring radius in glass eel otoliths, and that this variation could still be observed in young yellow eels. The tetracycline mark provided an unambiguous identification of eels belonging to the spring recruitment. The identification of autumn recruits was less easy. Within yellow eels collected in the springtime on the eel ladder, some were very small, but could not be confused with spring recruits, which were still at the glass eel stage. Indeed, spring recruits were freshly arrived in estuary, i.e. in April, because there is almost no escape from the fishery before its closure (BRIAND et al., In press). Among yellow eels, the boundary between autumn recruits (age 0 ) and spring recruits arrived the year before (age 1) was more difficult to establish and was based on otolith shape criteria.

To resume with, in spring, glass eels freshly arrived had otoliths with little marginal growth beyond the transition ring. Autumn recruits had a larger margin. In both groups, the deposition of the opaque marginal zone corresponding to the spring period of rapid growth was not sufficient to distinguish the translucent ring at the margin of the otolith. In opposition, eels from the previous springtime had a large marginal opaque zone deposition and displayed a translucent ring.

The second step was to test whether the differences between autumn and spring glass eels were stable in time. Indeed, the seasonal variations of the transition ring radius are not necessarily stable between years according to GUÉRAULT et al. (1995) and DE CASAMAJOR et al. (2001b). The outcome from these results was that a yearly stability of the seasonal trend seemed doubtful, and that analysis should be limited to the 1997-1998 cohort for which we had obtained values of the spring and autumn radius.

The long-term variation of otolith characteristics has also to be taken into account. Our results show that there has been a decrease in transition ring radius in the Vilaine since 1990 (GUÉRAULT et al., 1992; GUÉRAULT et al., 1995). The same trend was observed on the Adour (DE CASAMAJOR, Pers. comm, DE CASAMAJOR et al. 2001b). These variations in otolith size corresponded to the general long-term decrease in glass eel size and condition (DEKKER, 1998), which could be due to oceanic events (DÉSAUNAY and GUÉRAULT 1997; DE CASAMAJOR et al. 2001b).

However, these temporal variations were not detectable during our study, as the GLM showed that the temporal effect was not significant (Table 3). The absence of a significant temporal effect may partly be explained by the increasing variance of 


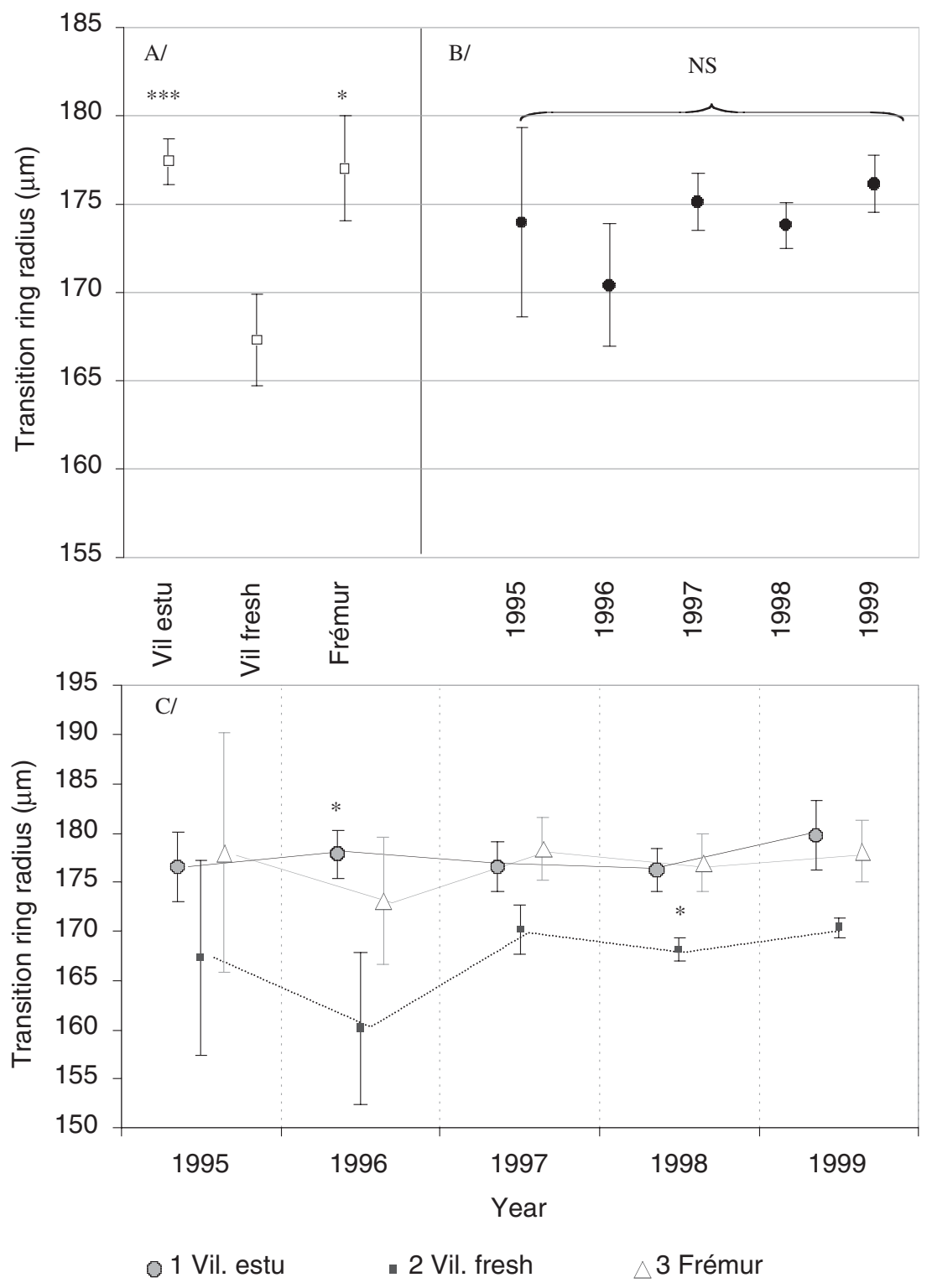

Figure 5

GLM analysis for model transition ring radius=location + cohort + cohort ${ }^{\star}$ group. $\mathbf{A}$ Least mean squares +-SE and Bonferroni test results for difference between groups, Vil fresh=Vilaine freshwater, Vil estu=Vilaine estuary, Frémur. Comparison with Vilaine Freshwater, ${ }^{* \star *} p<0.001,{ }^{*} p<0.05$. B/ Least mean squares +-SE and Tukey test results for difference between cohorts, no significant difference found. C/ Least mean squares +- SE and Tukey test results for difference between crossed effect (cohort ${ }^{*}$ group). No significant difference between groups except one case: $p<0.05$ between Vilaine estuary 1996 and Vilaine freshwater (*).

Figure 5

Analyse GLM du modèle transition ring radius=location+cohort+cohort*group. $A$ / Ajustement des moindres carrés, +-erreur type et test de comparaison de moyenne de Bonferroni pour la différence entre group, Vil fresh=Vilaine fluviale, Vil estu=Vilaine estuaire, Frémur. Comparaison à Vilaine fleuve, ${ }^{\star \star \star} ~ p<0,001,{ }^{*} p<0,05$. B/ Ajustement des moindres carrés +-erreur type et test de comparaison de moyenne de Tukey pour la différence entre cohortes (pas de différence significative). C/ Ajustement des moindres carrés +- erreur type et test de comparaison de moyenne de Tukey pour la différence entre effets croisés (cohortgroup). Une seule différence $p<0,05$ entre Vilaine estuaire 1996 et Vilaine eau douce $1998\left(^{*}\right)$. 
measurements as the eels grow older and otoliths get larger and more difficult to observe (figure 5B). The remarkable stability in estuarine transition ring radius implies that there was a year-to-year stability in the process coupling seasonal decrease in transition ring size, mortality and recruitment (Figure 5C).

As a consequence, we conclude that the interpretation of the otolith characteristics in young yellow eels, as described in this paper, provides a reliable method for tracing and determining the season of arrival of glass eels in estuaries. Such a result has already been observed in the silver eel (HOLMGREN et al., 1997) and suggests that mortality may smooth seasonal or annual variations in transition ring radius.

The otolith transition ring distributions varied significantly between sites suggesting that the stocks are composed of a variable proportion of spring glass eels (figure 5A). The lowest proportion of autumn eels was found in the freshwater part of the Vilaine, whereas the Vilaine estuarine eels and the Frémur freshwater eels display a large transition ring radius close to the autumn characteristics.

There is a large difference between the freshwater habitats of the Vilaine and the Frémur. So the differences in seasonal groups contributions could be explained firstly by invasion behaviours depending on sites: the Frémur river is much shorter and most sampling sites are more rapidly accessible for autumn eels compared to the Vilaine watershed. The other point is that there is no glass eel fishery in the Frémur River system and no related fishing mortality. A higher proportion of autumn and winter glass eels thus survives and colonises the freshwater habitats. The last point is that a different migration route in the sea between north and south Brittany may lead to a geographical discrepancy in transition ring size.

Within the Vilaine River system, the higher proportion of autumn eels in the estuary than in freshwater can be explained by the Arzal dam, which isolates the freshwater and estuarine populations, and leads to a difference in population dynamics in each compartment. The temporal stability in transition ring radius may be contrasted with the year-to-year variation in recruitment observed on the Arzal eel ladder (BRIAND et al., In press). There may however be a relationship between recruitment and transition ring radius: the smallest transition rings occurred in 1996 both in the Vilaine and in the Frémur freshwater habitats. In both systems this was the year when the dams were equipped with eel ladders. These results suggest that the access to low-density habitats was improved and that this improvement mainly eased spring recruits. In addition, in the Vilaine catchments, the 1998 cohort, which represented the highest fluvial recruitment ( $700 \mathrm{~kg}$ of glass eels), had a slightly smaller transition ring than the 1997 and 1999 cohorts, which had low recruitment levels (70 and $250 \mathrm{~kg}$ ) (BRIAND et al., In press). This low transition ring value was highlighted by the only significant difference found in pairwise comparisons of location*cohort groups which included the 1998 fluvial cohort (Figure 5C).

The striking outcome from these results is the importance of the proportion of autumn recruits in the Vilaine and the Frémur. On the one hand, calculations from transition ring radius imply that the freshwater yellow eel population consisted of about $32 \%$ autumn eels and that this proportion increased to $85 \%$ in estuary. On the other hand, focusing on glass eel recruitment, autumn recruits only accounted for 0.2 to $0.6 \%$ of the total fluvial recruitment (BRIAND and FATIN, 2002). The discrepancy between the recruitment estimation and the final population level may indicate: (1) that there was a problem in using transition ring radius, or (2) that the autumn recruitment was not well recorded, or (3) that there has been a large differential mortality between spring and autumn glass eels. 
(1) The calculation of the respective contribution of each cohort to the final population has to be considered as a rough calculation because of the small size of the seasonally related samples. However, because they were based on samples of spring and autumn eels collected at the yellow eel stage, the mean transition ring radius can be considered as a valid measurement. Indeed, the eels identified as autumn recruits within the spring ladder sample, displayed a wide range of sizes $(80-120 \mathrm{~mm})$ and a wider range of transition ring radius than the spring sample. These variations were possibly the result of a variable growth, but could also have been the result of a mixing of several waves of glass eels with different transition ring radii and different survival conditions from August to November. The yellow eel sample therefore integrates the final contribution of autumn glass eels to the population.

In the same way, the yellow eels identified as spring recruits corresponded to the marking from May to June of the main run of glass eels recorded on the ladder, and were representative of this run.

(2) In freshwater, the recruitment was carefully monitored on the eel ladder, and the very limited number of glass eels migrating from August to November could not explain the very large autumn eels contribution. However, three other sources of autumn recruits could be found. The first was made of yellow eels migrating through the eel ladder and the vertical slot fishway. Their number varied from 9540 to 35320 eels per year from 1996 to 1999 (BRIAND and FATIN, 2002). These yellow eels had a large transition ring radius. Indeed, there was no difference in transition ring size between samples collected on the trap and in the estuary and the otolith shapes were identical, with large and regular spaces between the winter marks. The second source corresponded to the migration at the glass eel stage through the sluice. The annual glass eel weight was evaluated to range from 10 to $30 \mathrm{~kg}$ in 1997 and 1999 (unpublished results). This additional recruitment was not large when compared to the eel ladder trapping as a whole, but it outnumbered autumn recruits. The third and probably main source of autumn recruits was the passage through the sluice and dam overflow panels at the yellow eel stage. The size of this recruitment could not be estimated but it was supposed to be large as eels use sluices during their migrations (BARAS et al. 1996; VERDON and DESROCHERS 2000).

In the estuary there was a large uncertainty in recruitment level. From August to November some glass eels were always caught on the eel ladder and this indicates that there was a continuous recruitment in the estuary. In November, at the beginning the fishing season, the fishing pressure was low with only one to ten boats per night, and there was possibly an escapement (BRIAND et al., In press). But as the fishing pressure increases in December, a large survival of November glass eels seems doubtful.

Therefore, in both cases, the size of autumn recruitment was probably very limited when compared to spring recruitment.

(3) As the two previous points fail to explain the large contribution of autumn eels to the freshwater and estuarine population, the third assumption is probably right and a very large mortality of spring glass eels settling in the estuary may explain their small contribution to the stock. This large mortality may be the consequence of a sizedependent mortality, exacerbated by density-dependent factors. Autumn recruits have larger energy reserves than spring eels (BOËTIUS and BOËTIUS, 1989; GUÉRAULT et al., 1995). They also display a better survival and growth rate in rearing experiments than glass eels arriving from January to March (SANTOS and WEBER, 1992). In addition, they arrive a few months before spring recruits in the estuary, and in spring they have already completed their metamorphosis. Size-dependent mortalities are reported in juvenile cod, with a survival of a 0 group released at sea increasing from 2 to $75 \%$ when the size at release was increased from 8 to $12 \mathrm{~cm}$ (DEKKER, 1998; 
KRISTIANSEN et al., 2000). In a review of mortality rates encountered by estuarine glass eels, KNIGHTS et al. (2001) noticed «Natural mortality of glass eel is relatively high and exacerbated by density-dependent effect during the time between their entry into estuaries and the metamorphosis and migration of elvers. Density-dependent Mortality would be exacerbated if migration is delayed in long estuaries or inhibited by barriers, e.g. as in the Severn and Vilaine respectively».

This paper shows that seasonal changes of transition ring radius may provide a tool for investigating eel population dynamics at the glass eel/ young yellow eel stage. Because of overlapping distributions, it will not be possible to differentiate seasonal recruits at the individual level, but results may be obtained at the population scale. The identification of autumn eels based on the otolith margin characteristics should be confirmed. It also indicates that the survival rate is very low for glass eels settling in the estuary in springtime.

\section{REFERENCES}

ALCOBENDAS M., LECOMTE-FINIGER R., CASTANET J., MEUNIER F. J., MAIRE P. and HOLL M., 1991. Technique de marquage en masse de civelles (Anguilla anguilla L.) par balnéation rapide dans le fluorochrome. Application au marquage à la tétracycline de $500 \mathrm{~kg}$ de civelles. Bull. Fr. Pêche Piscic., 321, 43-54.

BARAS E., PHILIPPART J. C. and SALMON B., 1996. Estimation of migrant stock yellow eel stock in large rivers through the survey of fish passes : a preliminary investigation in the river Meuse. In Stock assessment in Inland fisheries (ed I. G. Cowx), pp. 83-92. Fishing News Books, London.

BOËTIUS I. and BOËTIUS J., 1989. Ascending elvers, Anguilla anguilla, from five European localities. Analyses of pigmentation stages, condition, chemical composition and energy reserves. Dana, 7, 1-12.

BRIAND C. and FATIN D., 2002. Suivi de la passe à anguille du barrage d'Arzal : bilan 1996-2000. Report, Institution d'Aménagement de la Vilaine, 17 p. + annexes.

BRIAND C., FATIN D., FEUNTEUN E. and FONTENELLE G., In press. Estuarine and fluvial recruitment of European glass eel in a fished Atlantic estuary. Fish. Man. Ecol.

CHARLON N. and BLANC J. M., 1982. Etude des civelles d'Anguilla anguilla L. dans la région du bassin de l'Adour. 1. Caractéristiques biométriques de longueur et de poids en fonction de la pigmentation. Arch. Hydrobiol., 93.

CIERI M. D. and MC CLEAVE J. D., 2001. Validation of daily otolith increment in glassphase American eels Anguilla rostrata (Lesueur) during estuarine residency. J. Exp. Mar. Biol. Ecol., 257, 219-227.

DE CASAMAJOR M. N., LECOMTE-FINIGER R. and PROUZET P., 2001a. Détermination de l'état d'amaigrissement des civelles (Anguilla anguilla) en migration en zone côtière et estuarienne. C. R. Acad. Sc. Paris, 324, 345-353.

DE CASAMAJOR M. N., LECOMTE-FINIGER R. and PROUZET P., 2001b. Passé larvaire des civelles, Anguilla anguilla, (Linné, 1758) en migration en zones côtière et estuarienne (Adour, Golfe de Gascogne) à partir de l'examen des otolithes. C. R. Acad. Sc. Paris, 324, 1011-1019.

DEKKER W., 1998. Long-term trend in the glass eels immigrating at Den Oever, The Netherland. Bull. Fr. Pêche Piscic., 349, 199-214.

DEKKER W., 2000. A procrustean assessment of the European eel stock. ICES J. Mar. Sci., 57, 938-947.

DÉSAUNAY Y. and GUÉRAULT D., 1997. Seasonal and long-term changes in biometrics of eel larvae : a possible relationship between recruitment variation and North Atlantic ecosystems productivity. J. Fish. Biol., 51, 317-339.

ELIE P., LECOMTE-FINIGER R., CANTRELLE I. and CHARLON N., 1982. Définition des limites des différents stades pigmentaires durant la phase civelle d'Anguilla anguilla L.. Vie Milieu, 32, 149-157. 
FEUNTEUN E., ACOU A., GUILLOUËT J., LAFFAILLE P. and LEGAULT A., 1998. Spatial distribution of an eel population (Anguilla anguilla) in a small coastal catchment of northern Brittany (France). Consequences of hydraulic works. Bull. Fr. Pêche Piscic., 349, 129-139.

GUÉRAULT D., DÉSAUNAY Y., LECOMTE FINIGER R., GRELLIER P. and BEILLOIS P., 1995. Biometry and otolithometry of Anguilla anguilla (L.) glass eels : towards a model for seasonal variation. In VIII th SEI Congress, OVIEDO, 8p.

GUÉRAULT D., LECOMTE-FINIGER R., DÉSAUNAY Y., BIAGANTI-RISBOURG S., BEILLOIS P. and GRELLIER P., 1992. Glass eels arrivals in the Vilaine estuary (Northern Bay of Biscay) in 1990: demographic features and early life history. Irish Fish. Investig., 36, 5-14.

HOLMGREN K., WICKSTRÖM H. and CLEVESTAM P., 1997. Sex-related growth of European eel, Anguilla anguilla, with focus on median silver eel age. Can. J. Fish. Aquat. Sci., 54, 2775-2781.

KAWAKAMI Y., MOCHIOKA N., MORISHITA K., TOH H. and NAKAZONO A., 1998. Determination of the freshwater mark in otoliths of Japanese eel elvers using microstructure and Sr/Ca ratios. Environ. Biol. Fish., 53, 421-427.

KNIGHTS B., BARK A., BALL M., WINTER E. and DUNN S., 2001. Eel and Elver stock in England and Wales - status and management options. Environment agency. RetD technical report $\mathrm{N}^{\circ} \mathrm{W} 248,294 \mathrm{p}$.

KRISTIANSEN T. S., OTTERÅ H. and SVÅSAND T., 2000. Size-dependant mortality of juvenile reared Atlantic cod released in a small fjord. J. Fish Biol., 56, 792-801.

LECOMTE-FINIGER R., 1992. Growth history and age at recruitment of European glass eels (Anguilla anguilla) as revealed by otolith microstructure. Mar. Biol., 114, 205-210.

LECOMTE-FINIGER R., DÉSAUNAY Y., GUÉRAULT D. and GRELLIER P., 1993. The immigration of Anguilla anguilla (L.) glass eels in coastal waters : question about the determinism of the otolith structures. EIFAC, working party on eel, $5 \mathrm{p}$.

LECOMTE-FINIGER R., BIAGANTI-RISBOURG S., DÉSAUNAY Y., GUÉRAULT D., FOURCAULT B., PLANES S. and YAHYAOUI A., 1992. Age at recruitment of Anguilla anguilla glass-eels on the eastern Atlantic coast as inferred from otolith increments. Irish Fish. Investig. Serie A.

LOBÓN-CERVIÁ J., UTRILLA C. G. and RINCÓN P. A., 1995. Variations in the population dynamics of the European eel Anguilla anguilla (L.) along the course of a Cantabrian river. Ecol. Freshwat. Fish, 4, 17-27.

MICHAUD M., DUTIL J. D. and DODSON J. J., 1988. Determination of the age of young American eels, Anguilla rostrata, in fresh water, based on otolith surface area and microstructure. J. Fish. Biol., 32, 179-189.

MORIARTY C., 1986. Riverine migration of young eels Anguilla anguilla (L.). Fish. Res., 4, 43-58.

MORIARTY C. and DEKKER W., 1997. Management of the European eel. Fish. Bull., 15, 1-110.

MOUNAIX B., 1992. Intercalibration et validation des méthodes d'estimation de l'âge de l'Anguille européenne (Anguilla anguilla, L.). Application au bassin versant de la Vilaine, Bretagne. Thèse ingénieur, ENSA Rennes, 146p.

PANFILI J. and XIMÉNĖS M. C., 1994. Evaluation de l'âge et de la croissance de l'anguille européenne (Anguilla anguilla L.) en milieu continental: méthodologies, validation, application en Méditerranée et comparaisons en Europe. Bull. Fr. Pêche Piscic., 335, 43-66.

SANTOS M. A. and WEBER M., 1992. Growth studies on monthly captured glass eels from the Rio Minho in two recirculation systems. Irish Fish. Investig. Serie A, 36, 35-40.

SVEDÄNG H., 1999. Vital population statistics of the exploited eel stock on the Swedish West coast. Fish. Res., 40, 251-265.

TZENG W. N. and TSAI Y. C., 1994. Change in otolith microchemistry of the Japanese eel Anguilla japonica, during its migration from the ocean to the rivers of Taïwan. J. Fish. Biol., 45, 671-683. 
VERDON R. and DESROCHERS D., 2000 in press. Upstream migration movements of American eel (Anguilla rostrata) between the Beauharnois and Moses-Saunders power dams on the St. Lawrence river. 
